\title{
Impact of international accreditation in the recognition of academic degrees in the domestic and foreign labor market. Case study: Civil engineering program (Impacto que tiene la acreditación internacional en el reconocimiento de grados académicos en el mercado laboral nacional y extranjero. Caso de Estudio: Programa de Ingeniero Civil)
}

\author{
José Barragán Codina \\ Daniel Bortoni Herrera*
}

\begin{abstract}
In a globalized era it is not enough to have a professional qualification to ensure economic and professional success. The academic background of professionals must be adequate to face challenges and solve problems of a globalized and dynamic world. Civil engineers face many complications when seeking an international career. There are many differences within the profession globally such as: resources, workforce, climate, language, culture, philosophies, regulations, etc. which raise the entry barriers to fully practice as a civil engineer. The International accreditations play a major role as the first evidence of the civil engineer technical proficiency. These assure the quality of the higher education curricula and add value to the human capital on an international context. Despite the fact that many Mexican Universities have academic programs which have international accreditations, civil engineer graduates cannot easily work across borders. This paper describes the impact that international accreditation has for civil engineers when seeking an international career.
\end{abstract}

Keywords: accreditation, higher education, self-study, universities

JEL: $123,125,128$

\footnotetext{
- Universidad Autónoma de Nuevo León, Facultad de Contaduría Pública y Administración, San Nicolás de los Garza, N.L., México. Email: jose.barraganc@uanl.mx

* Universidad Autónoma de Nuevo León, Facultad de Ingeniería Civil, San Nicolás de los Garza, N.L., México. Email: danielbh88@gmail.com
} 
Resumen: En la educación global, no es suficiente el tener una calificación profesional para asegurar el éxito económico y profesional. La formación académica de los profesionales debe ser adecuada para enfrentar los retos y resolver los problemas de un mundo globalizado y dinámico. Los ingenieros civiles se enfrentan a muchas complicaciones en la búsqueda de una carrera profesional en el plano internacional. Hay muchas diferencias dentro de la profesión a nivel mundial, tales como: recursos, mano de obra, clima, idioma, cultura, filosofías, reglamentos, etc., que elevan las barreras de entrada para ejercer plenamente como ingeniero civil. Las acreditaciones internacionales desempeñan un papel importante como la primera evidencia de la capacidad técnica del ingeniero civil. Estos aseguran la calidad de los planes de estudios de enseñanza superior y agregan valor al capital humano en un contexto internacional. A pesar de que muchas universidades mexicanas tienen programas académicos que cuentan con acreditaciones internacionales, los graduados de ingeniería civil no pueden trabajar fácilmente a través de las fronteras. En este trabajo se describe el impacto que la acreditación internacional tiene para los ingenieros civiles en la búsqueda de una carrera internacional.

Palabras clave: acreditación, auto estudio, educación superior, universidades

\section{Introducción}

Accreditation is a voluntary process initiated by an institution in which educational programs are evaluated by accrediting bodies to meet certain quality standards. An accredited program undergoes a rigorous review before accreditation can be granted and are periodically evaluated to insure continued compliance with the established standards and policies.

An Accredited program not only demonstrates quality of the education, but also enables mobility as it lowers the barriers for academic credit transfer and recognition of degrees internationally.

Civil Engineers, as professionals, have a great impact on the welfare of societies. They are involved in the development and maintenance of essential projects including transportation systems, water distribution systems, and buildings for diverse purposes, to name just a few. As boundaries between nations are being lowered to enter a globalized and dynamic world new challenges appear. Civil engineers must keep pace with global opportunities and assume an active role. However, this task has been a very complicated subject. 
"Professional recognition of civil engineering qualifications is generally straightforward at a national level, however across a border it can become a serious problem and, indeed, civil engineering is not a regulated profession in some countries. Hence mobility continues to be a very difficult issue, despite international accreditation agreements and accords".Sanjuan (2010)

As stated by Soeiro (2006), "the active engineer wants to have the chance to look for other job opportunities in other countries. The engineer needs some form of recognition of his qualifications obtained through formal education and as a result of the professional experience obtained on the job".

Mutual recognition of degrees between countries is necessary for civil engineers in order to maximize their potential and thus benefit communities. Higher education systems must improve their curricula to prepare future engineers with the necessary skills and competences to succeed globally. As described by Chan \& Fishbein (2009), some key attributes of the global engineer are:

- communication skills and understanding of different cultures and languages;

- a facility for multidisciplinary and interdisciplinary teamwork;

- a well-developed sense of social responsibility and ethics, with due consideration in his/her personal and professional activities;

- being entrepreneurial; and

- an ability to deal with complexity and systems thinking.

Future engineers will help provide both ethical and sustainable solutions to tackle the global challenges and create the infrastructure needed by a globalized society.

This study aims to see the current outlook of civil engineers. Civil engineering programs throughout Mexico are accredited by national and international bodies. What is the impact of accreditations when seeking an international career? Are the civil engineer graduates prepared with the competences needed on a global context?

\section{Theoretical framework}

On his research Fishbein (2009) states that "global engineers should understands and propose solutions for many of the complex emerging global 
issues". Lenn (2000) emphasizes that "the global marketplace has accentuated the need for cross-border movement of professionals, thus providing additional pretense for international trade". Codina (2010) accentuates about "the importance of specialized graduates, capable of visualize risks and opportunities in the international plane. About how graduates must possess research and customer-focused abilities as well as international experience within the professional degree".

The need for global engineers is not a new subject. Universities must adopt an active position and improve their curricula in order to prepare engineers with the competences needed for any upcoming challenges. On his research, Riemer (2007) describes the importance of the communication skills of the "new engineer" and states, "Engineering graduates require an everincreasing range of skills to maintain relevance with the global environment of the new millennium".

Not only technical skills are needed, as stated by Bourn \& lan (2008) "Higher education needs to prepare engineers of the future with the skills and know-how they will need to manage rapid change, uncertainty and complexity. Key here is the ability to tailor engineering solutions to the local social, economic, political, cultural and environmental context and to understand the impact of local action on the wider world". The accreditation bodies play a major role as the main assurance of quality of higher education programs. The term "accreditation" can be described as follows:

According to the Accreditation Board for Engineering and Technology ABET (2015), accreditation is a review process to determine if educational programs meet defined standards of quality.

According to the Accreditation Council for Engineering Education or ins Spanish: Consejo de Acreditación de la Enseñanza de Ingeniería CACEI (2015) accreditation of a higher education program is the public acknowledgment granted by an accrediting body which ensures the program complies with a determined set of quality criteria and parameters". Jones (2003) defines accreditation applied to engineering as a certification that an educational program meets a certain set of standards agreed upon by an authorizing entity. 
Espinoza \& González (2013) stated, "Institutional and program accreditation represents the seal of quality by a public entity and/or private institution, where in the latter case it has a long term vision which consists of a commitment to excellence and guarantees regarding key aspects such as the coherence of the curriculum, teacher quality and the trajectory of alumni".

From these assertions the question that arises is: What is the impact of accredited programs of Mexican universities when graduates pursue an international career?

\section{Civil engineering profession in Mexico and the United States}

Civil engineers are involved directly in the development of societies. With the rise of global needs, many engineering projects are executed remotely, even across countries. Capable professionals are needed to face emerging challenges and complexities. Engineers must be prepared with the necessary competencies and skills to perform projects successfully and deliver functional, and economical solutions.

\section{Educational outlook}

In Mexico and the U.S.A. the length of studies of the civil engineer program ranges from 8 to 10 semesters. Bachelor's degree programs include coursework in physics, statistics, engineering mechanics, calculus, structural analysis, among other courses.

As shown in Table 1 there are 110 civil engineer bachelor programs offered in Mexico which are affiliated to the ANNUIES. Among these programs 50 are accredited by the CACEI (2015) and only 4 are accredited by the Accreditation Board for Engineering and Technology ABET (2015) and are offered by the following institutions:

- Universidad Autónoma de Nuevo León (UANL)

- Instituto Tecnológico y de Estudios Superiores de Monterrey (ITESM)

- Universidad Autónoma de San Luis Potosí (UASLP)

- Universidad Autónoma de Aguascalientes (UAAGS) 
Table 1. Mexico, civil engineer statistics 2013-2014 (absolut numbers)

\begin{tabular}{lc}
\hline Element & Bachelor Degree \\
\hline Institutions & 90 \\
Programs & 110 \\
Enrollment & 57,478 \\
Applications & 23,436 \\
Places offered & 13,202 \\
Total Graduate & 5,746 \\
\hline
\end{tabular}

Source: ANUIES, Own elaboration with data from 911.9A 2013-2014 questionaries.

\section{Licenses, certifications and registrations}

After the successful completion of the engineering program, graduates must pass a final exam or thesis to get a federal professional engineering license and the B.S. degree. This license not only allow Mexican engineers to practice their profession nationwide by being able to sign engineering documents, but also protects the public by preventing unqualified people from offering engineering services.

In the USA the process is different. Licensure is regulated at a state level; which means for an engineer to practice in multiple states, he or she must become licensed in each state.

Although the process is similar in all states, each has its own procedures. However, as described by the National Council of Examiners for Engineering and Surveying NCEES (2015), which is the organization that develops, administers and scores the examination used for engineering licensure, there is a general four step process for licensure candidates:

- Earn a degree from an ABET-accredited program.

- Pass the Fundamentals of Engineering (FE) Examination.

- Gain acceptable work experience (typically a minimum of 4 years).

- Pass the Practice of Engineering (PE) examination.

Once all the registration requirements are met the title of Professional Engineer P.E. is granted. Although it is not mandatory to be licensed to work as a civil engineer, it is necessary to sign and seal engineering documents and to become a consulting engineer. As stated by Adams (2008) "Being presented with the title professional is an honor that should not be treated 
lightly, as any career in a field by which service is offered to society brings great reward".

\section{Employment and payment}

According to the National Survey of Occupation and Employment, the average monthly income in Mexico, was $\$ 12,738$ Mexican Pesos for the 1st quarter of 2015. While in the USA, according to the Bureau of Labor Statistics, the average monthly income was 7,260 US Dollars in May 2014.

\section{International accreditations. Conceptual definitions and process}

It is important to establish what an accreditation is. Accreditation can be defined as:

"A recognition given by external evaluators stating that an institution and/or specific career is doing everything to prepare the alumni with the necessary competences and skills required by the labor market."

"A university accreditation is a process to achieve a quality certification of the internal process within universities."

In simple terms, accreditation is an internal and external revision made to an institution to determine if the curricula have the necessary level to be certified by the evaluation bodies in order to ensure the professional graduates are in a competitive level nationally and internationally. Accreditations have multiple benefits for institutions and societies. The institution gets the advantage of the reputation added to its image. An accredited institution provides the public a guarantee of the quality of education, so that not only demand would increase but recognition as well. Societies with accredited schools have the capacity to generate prepared human capital to face the challenges of a globalized world. Which would generate better life conditions, welfare and an increasing development through foreign direct investment.

With an increasingly competitive labor market, educational institutions need to be evaluated to meet international standards. However, since the needs, resources and interests vary greatly among countries, it is extremely difficult to standardize curricula and educational competences. There are now 
national and international evaluator bodies whose function is to establish and ensure quality standards for educational programs.

In Mexico, the Council for Higher Education Accreditation or in Spanish Consejo Para la Acreditación de la Educación Superior, COPAES (2015), is the only recognized body by the federal government through the Public Education Secretariat or the Secretaría de Educación Pública, (SEP) that confers formal recognition to organizations whose purpose is to accredit academic programs of public and private Higher Education Institutions in Mexico.

The COPAES recognize a variety of accreditation bodies sectors such as the Accreditation Council for Engineering Education or in Spanish : Consejo de Acreditación de la Enseñanza de la Ingeniería, A.C. (CACEI), the Accreditaiton Council for Arts in Higher education, or in Spanish: Consejo para la Acreditación de la Educación Superior de las Artes A.C. (CAESA), the Council for Accreditation for Humanities Higher Education, or in Spanish: Consejo para la Acreditación de Programas Educativos en Humanidades, among many others.

\section{Benefits of international accreditation}

Among the many benefits of international Accreditation the following can be listed according to the Peru's National Presidents Asambly, or Asamblea Nacional de Rectores de Perú:

- For students:

- Ensure the quality of offered educational programs.

- Achieve credit transfer and facilitate the acceptance to higher levels of educational programs.

o It is a way to acknowledge the educational quality of a program and the institution.

- For universities:

- Promotes continuous improvement.

- Ensures an external evaluation of an international level that meets the expectations of society.

- Allows updating study plans and curricula.

○ Reduces public control and is governed by global educational trends. 


\section{Government position regarding international accreditation}

For the COPAES, in Mexico, the government assumes a regulatory role of the external and international assessments. The organization is dedicated to establish regulatory frameworks as follows:

- Submittal of proposal of guidelines and criteria to recognize the legality of national accreditation bodies.

- Statement of a common framework of criteria for the accreditation of educational programs.

- Evaluation of the national accreditation bodies.

- Publication of the national accrediting agencies recognized by them in directories

\section{Types of international accreditations}

Currently, the accrediting agencies offer two kinds of international accreditation.

1. Institutional accreditation. - Comprises an evaluation of the whole institution as an educational entity assigning an accreditation that measures the level of quality in different areas such as: educational programs, teaching staff, operating systems, student services, linkage with community, among others.

2. Accreditation per program. - This type of accreditation is primarily focused on the different aspects of the curricula offered, such as: educational model, content, program vision, and primarily on the entry and egress profile.

Universities can decide which type of accreditation to achieve depending mainly on the security and recognition of the accrediting agency, the allocated budget the support of the teaching staff and the resources. 


\section{Mechanism for the planning of the assessment}

As shown in Figure 1, once the institution has decided to conduct the external evaluation, the process begin with the application for a membership with the Accrediting Agency. Also, almost simultaneously, the planning of all the required activities to meet the accreditation standards and criteria begins. This stage involves the compilation of information as evidence of criteria compliance. The resulting information is then summarized and presented as the self-study.

Figure 1. Process within international accreditation

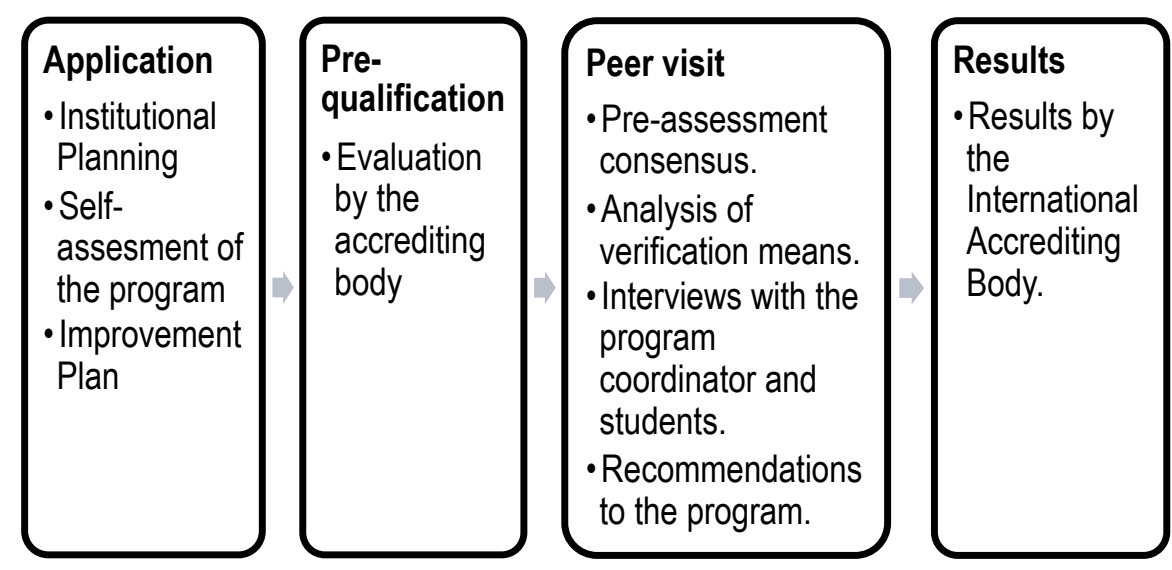

Source: http://www.abet.org, www.sacs.org

The third step is known as the peer visit. For most international agencies the assessment process is carried out worldwide with reviewers traveling internationally to facilities. Finally, the fourth step is the assessment report, where the Accrediting Agency gives resolution whether the university or program becomes accredited. 


\section{Organizational structure of accreditation bodies}

As shown on Figure 2 the operative structure of each accrediting agency consists of three groups: The accreditation commission, the technical committees and the evaluating peers or auditors. The functions of each group are described as follows.

Figure 2: Technical committees functions

\section{Accreditation Comissions}

- Set up the standards, procedures and requirements for accreditation.

- Nominate the members of the Technical Committees.

- Nominate the Audit-Teams.

- Issue the accretitation decision on the basis of the peer review results
Technical Comittees

- Develop and Improve the fieldspecific criteria for the study.

- propose the experts for the audit-teams.

- Check report statements of the peers.

- Make a recommentation to the accreditation comissions.

\section{Audit Teams}

- 4-5 persons (Industry and both types of universities)

- Briefing

- View documents of the University

- Visit and interview the University (2 days)

- Create final report

- Coordinate the final report with the university.

- Give report and statement with recommendations to Technical Committees and Accreditation Commission. 


\section{The accreditation commission}

This commission is mainly formed by recognized professional experts in the area of knowledge. Most often are academics or professionals with broad experience, some already retired that agreed to form part of these commissions.

Their main function is to receive the self-study of the candidate entity to be accredited, once the study is examined, the commission dictates whether it is subject or candidate to be accredited. In some cases, the commission recommends or suggests changes in educational programs or models before competing for international accreditation. In some cases, the commission may also suggest to obtain first the national accreditation, and subsequent to this, the international accreditation. Once the final decision takes place the application and the self-assessment is delivered to the technical committees.

These groups of peer reviewers have as primary function to establish evaluation standards Their job is very interesting and innovator because they transform the educational tendencies in evaluation or revision standards. This sum of criteria is transformed into guides to perform comparative evaluation among the standards and the operative development of the academic program.

It is considered a good practice to organize an annual conference to present both, the members of the accreditation agency as well as potential candidates, the evaluation standards. And in parallel in those events are organized workshops to describe how the evidence is gathered to comply with the accreditation standards. Technical committees are one of the columns of each accrediting agency, so it should be subject to a careful selection of members

\section{Requirements for Mexican Universities}

It can be mentioned that the educational policy of accreditation in Mexico began in the 90s, where the objective was the evaluation of the educational processes at the universities. The Federal government created the Federal Inter-institutional Commite for Higher Education Evaluation or in Spanlish: Comités Interinstitucionales para la Evaluación de la Educación 
Superior (CIIES). Their main task was to diagnose and evaluate educational programs without being considered an accreditation. It was until 2000's that the Public Education Secretariat (Secretaría de Educación Pública) (SEP) recognized the creation of the Council for Higher Education Accreditation or in Spanish: Consejo para la Acreditación de la Educación Superior (COPAES), and delegated the accreditation of academic programs of higher education of public and private universities. Buendía (2011)

Operationally, the COPAES do not accredits the educational programs, it only gives its backing to the organizations in charge of evaluating academic programs. Among its activities are the following:

- Development of criteria and guidelines to formally recognize the national accreditation bodies.

- Spread of nationally recognized accrediting agencies.

- Monitoring and supervision of academic rigor and impartiality of the accreditation bodies COPAES (2013)

The accreditation process is integrated, in most cases, in five stages:

1. Application for accreditation of educational program.

2. Compliance with the conditions of the accreditation process.

3. Preparation and presentation of a self-study that enables institutions to learn their inputs, processes, outcomes and the extent to which they contribute to corporate goals based on the guidance provided by the accrediting body.

4. Evaluation process by the accreditation body.

5. Final decision that mentions whether the program was accredited or not.

One of the authors of accreditation exercises, Rama (2009) states that accreditation can be used as a mechanism of differentiation to identify which universities cover certain requirements of educational quality. Sobrinho (2012) criticizes by noting that the main objective of accreditation is the bureaucratic, legal and formal control of quality assurance.

As can be seen, accreditation at that level is a tool of control and educational quality assurance. Later, it will be shown the international accreditation and what have been the global trends of countries and universities regarding the main objectives and functions of accreditation and what have been their impact within the academic management of institutions. 


\section{The cost of international accreditation}

Finally all comes to the cost of accreditation, or as some agencies call it: investment in quality assurance. The cost of accreditation process has a wide range of options, but a good practice is when the planning for having an international accreditation begins; it is convenient to keep in mind the following phases in the process:

- Phase 1: Selecting the agency:

- Check references and previous evaluations.

- Be sure to contact them (even e-mail) to verify proper identification. In some cases, for Mexican Universities, some agencies do not carry out accreditation outside the USA, like the APA. Some other do not offer an accreditation per se, they offer a "substantial equivalency" which technically is the same, but with another name for outside the USA.

- Verify if they are recognize by the CHEA (Council for Higher Education Accreditation). It means the agency has the US government approval.

- Phase 2. Starting the process:

- Be sure that the selected agency sent the accreditation standards or download them from their web page. Usually some agencies update the standards according with the year in course. This will give the Mexican university, an idea of the feasibility of the process. Some agencies may send some auditor, in this case the travel expenses as well as the auditor's fee has to be included.

- Phase 3. Membership:

- Some agencies require the membership as an initial fee. Others just do not.

- Phase 4: Subject of accreditation:

- Depending on the intention and objectives of the international accreditation, it can be selected form two types of international accreditation: Program accreditation or Institutional accreditation. Cost can be significantly different. In the Institutional type, cost and time could be higher.

○ In any case the university should ask for a consultation. 
- Phase 5: Accreditation Fee:

- It can go from $\$ 1,000$ USD to $\$ 30,000$ USD depending on the agency location (US or Europe as the most recurrent).

- Program or institutional accreditation impact on the cost, in this case, one recommendation for Mexican universities is to start with just one program at a time. This could be budget friendly.

\section{Final remarks}

As part of the remarks, is considerable to answer some questions that may arise to the accreditation topic, as follows:

- What is the impact of accreditations when seeking an international career? The international university rankings such as $Q$ Star, or the London Times Best Universities refer to the international accreditation of programs as one on the main decision elements when choosing university by students. So accreditation will be a main element in the decision.

- Are the civil engineer graduate prepared with the competences needed on a global context? Indeed, globalization comes along with a specific homologation of competences in every university and field of knowledge, as the education programs claim to be international. Also, this homologation in competences, bring the opportunity for country to idealize the mobility of professions, like the European Union has develop and practices nowadays.

- What is the impact of accredited programs of Mexican universities when graduates pursue an international career? The main benefit, is that the graduate form a Mexican accredited university program, is the recognition and validation of their education with the same quality standards of any other international recognition university. This also leads, as explained before, that the graduate from these programs, could obtain the professional exercise license issued by the foreign governments, as the graduate were an actual graduate from these programs. 
The civil engineering profession faces great challenges at a global level. Often, for example, a company can develop a project in South America by following North American design standards while engineered in a remote country. The graduate must possess a diverse set of skills and a continuous improvement mentality as the foundation for a satisfactory professional development.

Although the national and international accreditations are not mandatory in higher education institutions, these are important to ensure the quality of education and add value to both the institution, by giving public recognition, and to the alumni by providing a competent education on a national and international level. In some cases, having a degree from an accredited program may also enhance professional mobility, as a proof of an adequate academic background, towards an international career.

To standardize the curricula among institutions results a complicated task, even within the same country. However, it is important for higher education to adapt to the market needs and have a dynamic stance by continuously improving the educational programs. There is no doubt that international accreditation is one of the important trends within university planning. In terms of benefits, as previously discussed, the international accreditations are a seal of academic prestige, and in parallel with the national accreditations it is an instrument of educational quality assurance.

This study intends to explore the basic concepts and the critical factors such as, the standards, criteria and cost. This tool allows Mexican universities to cooperate with the placement of its graduates abroad through the recognition of their educational degrees, and above all, by developing in the alumni the needed skills to get a degree equivalency and thus recognition. The program in civil engineering is, as considered in this study, the eligible program that can be recognized in the international labor market, which is undoubtedly the response of education to the challenges of globalization faced by universities.

It must be noted, as the next step in the commercial agreements between countries, the mobility of professions and professionals, which has been successfully implemented in the European Union, and that can be undoubtedly the next step in the development of the Mexican commercial agreements with the world. 


\section{Referencias}

ABET. (2015, August). Accreditation Board for Engineering and Technology. Retrieved from: www.abet.org.

Adams, D. K. (2008). The structural engineer's professional training manual. New York: McGraw-Hill.

Bourn, D., \& lan , N. (2008). The global engineer. London: Institute of Education, University of London.

CACEI. (2015). Consejo de Acreditación de la enseñanza de la Ingeniería, A.C. Retrieved from: www.cacei.org.

Chan, A. D., \& Fishbein, J. (2009). A global engineer for the global community, The Journal of Policy Engagement, 1(2), 4-9.

CHEA (2015, August). Council for Higher Education Accreditation. Retrieved from: www.chea.org.

Codina, M. B. (2010). El Impacto de la globalización en la educación y el perfil del administrador internacional, Daena: International Journal of Good Conscience, 5(2), $239-245$.

COPAES (2015). Consejo para la Acreditación de la Educación Superior. Retrieved from http://www.copaes.org.

Espinoza, Ó., \& González, L. E. (2013). Accreditation in higher education in Chile: results and consequences. Quality Assurance in Education, 21(1), 20-38.

Fishbein, J. M. (2009). The global engineer: An implementation of outcomes-based. CDEN/C2E2 Conference, McMaster University, Hamilton, Ontario, 1-6.

Jones, R. C. (2003). Global accreditation trends. International Conference on Engineering Education, Valencia, Spain, 1-4.

Lenn, M. P. (2000). Higher education and the global marketplace: A practical guide to sustaining quality, On the Horizon, 8, 7-10.

National Research Council. (2005). Educating the engineer of 2020: Adapting Engineering Education to the New Century. Washington, DC: The National Academies Press.

NCEES. (2015, August). National Council of Examiners for Engineering and Surveying. Retrieved from www.ncees.org

Riemer, M. J. (2007). Communication skills for the 21st century engineer. Global J. of Engng. Educ., 11(1), 89-100.

Sanjuan, J. M. (2010). Engineering: Issues challenges and opportunities for development. Paris: United Nations Educational, Scientific and Cultural Organization.

Soeiro, A. (2006). Bologna process versus global engineer Education. 9th International Conference on Engineering Education. San Juan, PR, 1-6.

Sunedu (2015). Superintendencia Nacional de Educación Superior Universitaria. Retrieved from: www.sunedu.gob.pe/. 